\title{
Factors determining optimal Social Media Network portfolio for accounting firms: The case of the Czech Republic
}

\author{
Libuše Svobodová ${ }^{1}$ and Martina Hedvičáková ${ }^{2}$ \\ 1, 2 University of Hradec Králové, Rokitanského 62, 50003 Hradec Králové, Czech Republic \\ libuse.svobodova@uhk.cz, martina.hedvicakova@uhk.cz
}

\begin{abstract}
Over the last few years, online social networks have experienced exponential growth in both profile registrations and social interactions. They are widely used in the personal life but also in the business. The goal of the article is to state the most often used accounting software and their producers in the connection with use of social networks by producers of accounting software in the Czech Republic. The sub-goal is to present records gained from Socialbakers focused on the evolution of fans on Facebook and how a company decides on the use of the optimal mix of platforms. Classification of social networks, social media and accounting software are solved and shortly described at the first theoretical part. Main producers of accounting software and analysis of social networks that are used by producers of accounting software are presented in the main part of the article. It is also analyzed whether producers of accounting software have direct links from web pages on the selected social networks. The last part is devoted to selected social networks and how to use it in the companies producing accounting software. Selected topic is up-to-date and it is not often solved in the literature. The topic is important to the professional public. It was founded that most often used social network by producers of accounting software are Facebook, YouTube and Twitter. The links from web pages are often used also in the connection with Google+. All companies do not put links on the used social networks.
\end{abstract}

Keywords: Accounting software, Communication, Information, Social network, Use.

\section{Introduction}

Measuring and evaluation of company performance is carried out in companies through accountancy and other software. Producers of accounting software are trying to increase their efficiency and profitability and sell as many products and licenses as possible. This is related to communication not only with new customers but also with current ones. At present time, one of the major channels of communication is web sites and social networks. Their advantage over printed one is fast delivery, possible updates, or lower costs. Social networks are widely used not only in the personal life, but also in 
the commercial sphere. They have a lot of effects on the society. Increased online communication and fastened communication are some of them. The question may be whether the companies that produce accounting software in the Czech Republic use selected social networks for communication with their customers, potential customers, students and next audience. Businesses that would like to implement new accounting software take into consideration lot of criteria. One of the key elements in the selection may be communication with producer of the accounting software via various channels. Selection of new accounting software was solved in the previous research done by Svobodová, Černá [1].

The organization of the paper is follows. Firstly theoretical background is described. The main part of the article is focused on the evaluation of use of social networks by producers of accounting systems. The paper contributes to the exploration of utilization of Web 2.0 phenomenon and social networks by companies and individuals in the field of accounting software. Topic of producers of accounting software and communication via social networks were connected because companies are searching how to save money in all areas of doing business, earn more money, have a larger share on the market and other goals. Social media are very often perceived as the possibility how to save money in the communication with customers and how to engage attention. Contrary people like to use social networks that are nowadays modern, popular and often used not only by one generation.

\section{$2 \quad$ Literature review}

\subsection{Web 2.0}

Web 2.0 concept was defined by Tim O'Reilly in 2004 as a designation of the new generation of the Web. "Web 2.0 is the business revolution in the computer industry, which is caused by deflection in the understanding of the Web as a platform. Key among those rules is this: build applications that will be better and better due to the network effect with an increasing number of people." [2] Tim O'Reilly [2] defined the main differences between classical Web site and a new generation web. In terms of software development Web 2.0 is characterized as a shift from centralized processing and services to decentralization. Second generation web gave users the ability to handle their website and use social networks to converge with other users and attract potential customers. Web 2.0 is a term for applications where the user affects the content or communicates with other users. These applications then become social networks.

\subsection{Social networks}

A sociologist J. A. Barnes (1954) is considered to be the author of the definition of the social network. The term social network is associated with the Internet and directly with the social networks on the Internet. But this is not the only connection there is a need to deal with the concept of social network from the sociological point of view, therefore, the social network can be described as a "map of the area near and distant surroundings where relationships of involved people are defined." [3] 
Černá, Svobodová [4] presented in previous research the most often used social networks Facebook, Instagram and Twitter or Svobodová [5] use of YouTube.

Social networks have global popularity. One of the most common online activities in the EU-28 in 2017 was participation in social networking. More than half (54\%) of individuals aged 16 to 74 used the internet for social networking, for example using sites such as Facebook or Twitter in the EU [6]. According to Czech statistical office [7] $48.3 \%$ of individuals aged 16-74 use social networks in the Czech Republic.

\subsection{Social media}

Social media are applications which become social networks via users' use.

Social media are a form of electronic communication (social networking and microblogging networks), through which users create online communities to share information, ideas, personal messages and other content (videos). [8] Social media can be divided on the basis to marketing tactics as Social networks (Facebook, MySpace, LinkedIn); Blogs, video blogs, microblogs (Twitter); Discussion forums, Q \& A portals (Yahoo Answers); Wikis (Wikipedia, Google Knol); Bookmarking systems (Digg, Delicious, Jagg); Shared multimedia (YouTube, Flickr); Virtual worlds (Second Life, The Sims). [9]

How Brand Actions and User Actions Influence Brand Value by use of social networks is solved in [10] and performance measurement system to quantify the contribution of social media is presented in [11]. Du and Jiang [12] find that company use of social media is associated with firm performance, measured by stock price and return on assets. When testing the individual association of the various platforms and firm performance, the authors find that only Facebook and Twitter has a statistically significant relationship. They observe that half of the firms use one or both of these platforms.

\section{$2.4 \quad$ Accounting software}

The term refers to software accounting software that handles accounting and financial processes. The offer of accounting software focuses on the specific size of the company. According to company size amount of income, the number of transactions processed and the number of employees differs. There are special offers to the market according to company size small, medium and large businesses. Accounting software in each segment focuses on something else. At the level of small companies the offer covers standard accounting modules, such as purchase orders, payroll, billing, etc. Generally at this level the software runs on a separate system and supports multiple users who are incorporated into database software. The acquisition cost of such software is low and can be purchased as so called box software. Accounting software provides medium-sized organizations with complete components for processing of financial activity of the company which is usually specialized. The last segment of the large organizations is favouring the complex connections between companies using ERP systems. These systems are expensive. The development of the system itself is a tiny item in the final list. The largest expenses include consulting, training, workflow reengineering, organizational restructuring costs, installation and commissioning itself. [13] 


\subsection{The main purposes of selected social networks}

The subchapter contains theoretical background of purposes of selected social networks.

- Facebook - Facebook for marketing allows businesses, organizations and public figures to connect with customers, fans and constituents through the website. Businesses and other brands create pages where they can post content, provide organizational news, offer deals, introduce products and manage customer service relationships. They also can reach a large number of people with targeted advertising, creating ads specifically for Facebook that are tailored to appear on the pages of specific groups of people they hope to reach. [27]

- YouTube - companies might gain a lot from short videos on YouTube showing the benefits of their products and also videos how to use products. YouTube is all about getting visitors to stay and consume video after video so that they can see ad after ad. According to one small study, conducted by Phil Nottingham of Distilled, only $0.72 \%$ of viewers of YouTube channels with URL's in the description clicked thru to the linked site. What that tells us is, if you are trying to get people to come to your website, YouTube might not be the tool to click thru to the linked site. [28]

- Twitter - it is a social networking and microblog provider that allows users to send and read posts sent by other users, known as tweets. The main purpose of Twitter is to make profits for those running the business (founders, investors, employees and more). From a user's perspective, it may serve many purposes including but not limited to: Keep an eye on trending events/news, Connect with like-minded people, Marketing or promotion of business, Stalk and spam, Vent out emotions or anger, Business Support, Finding and connecting with influencers. [29]

- Google+ - the purpose of Google plus is to provide a binder to the web experience of a user. It is one of the top components of Google ecosystem now solving a multitude of problems not only for google but for the whole web. It also helps provide a web identity to users. [30] Glusman presented [31] 7 Reasons Why You Should Be Using Google+ For Your Business.

- LinkedIn - it is a professional social network where professionals meet and discuss their work interests and they are also looking for new employees. LinkedIn is a professional social media network, where users create profiles highlighting current and prior work experience. You can upload resumes, connect with colleagues and classmates and build a network that can help you advance in your career. [32]

- Instagram - the app allows users to upload photos and videos to the service, which can be edited with various filters, and organized with tags and location information. An account's posts can be shared publicly or with pre-approved followers. Users can browse other users' content by tags and locations, and view trending content. Users can "like" photos, and follow other users to add their content to a feed. [33] 


\section{Methodology and goal}

The goal of the article is to present the most often used accounting software, their producers in the connection with use of social networks by producers of accounting software and links with producer's web pages in the Czech Republic. The sub-goal is to present records gained from Socialbakers focused on the evolution offans on Facebook and how a company decides on the use of the optimal mix of platforms.

The article was prepared on the basis of print and electronic resources. Specialized articles that deal with issue of financial accounting or social media can be found. By contrast, printed literature on accounting (economic) software doesn't nearly occurs on the Czech market. Available books on accounting are primarily concerned with the processing and are intended for teaching or as a handbook for accountants. Specialized materials in the field of information technology are in particular focused on the area of enterprise information technologies and their application. Publications on ERP systems are available in this field and in most cases they contain accounting (economic) software, but they do not aim deeper on it. In contrast to the situation on the Czech market there are a lot of foreign sources abroad. In case that we link accounting software and their producers and social networks together there are not a lot of articles focused on this issue. The existing literature focused separately on the accounting software and Facebook or social media or social network in the connection of promotion of the brand or product, communication with customers or training etc. There were not founded relevant articles in databases Web of Knowledge or Scopus focused on the interconnected topic. This topic is still in its infancy. The intention of the article is to stimulate a conversation and proposes ways in which to frame early and future research.

The main part of the article is based on the available resources of the most often used accounting SW and their producers in the Czech Republic. Selected accounting SW will be applicable for SME. The selection was done due the highest proportion on the market. In the next step was done analysis whether the producers of accounting SW use selected social networks or not and whether are web pages of the producers connected with their social networks. Next part of the article is devoted to statistics of fans from individual companies. Data was obtained from Socialbakers [14]. The last part is devoted to optimal use of platforms by companies producing accounting SW.

\section{$4 \quad$ Results}

The first part contains the results of selection from accounting software products and their producers. Data were selected from the SystemOnLine website [15] which deals with statistical data about accounting, economic and ERP systems and with their use, information about functions, prices etc. in the Czech Republic. Accounting software for SME in the Czech Republic will be included into next processing. The second part contains information about social network Facebook, YouTube, Twitter, Instagram, Google+, LinkedIn and their use by accounting software producers. Next topic is focused on the interconnection of social networks with web pages of companies. 


\subsection{Accounting software and producers}

On the basis of gained results from the investigation a selection of the below discussed results have been made utilizing SystemOnLine website. Individual companies regularly update detailed information about accounting software products, including the number of installations, number of hot-line workers, number of consultants of the product, functions of the product, price, etc. In the filter it was firstly entered - find a product that has more than 10,000 installations. The following products were displayed: Ekonom, Pohoda, Money S3 and "Účto" (Accounting). Due the larger sample of the companies was the selection repeated with the smaller number of installations that were reduced on 5,000 installations. Into research will be added Abra Gen, Helios Orange and Stereo Ježek Software (SW). In the next search specific data of all other products were found. Table 1 shows all the above mentioned accounting software and ERP systems. Pohoda with more than 200,000 licenses and Money S3 with more than 60,000 licenses are the most widely used box systems in the Czech Republic. Ekonom has representation in 35,000 licenses followed with other product Účto Tichý with 24,200 licenses on the second type of accounting in the Czech Republic that use most of the business entities. In table 1 there are presented name of product, name of producers, number of installations, size of the biggest installation, workers on hot-line and number of consultants of the product. Some data were not filled in by the companies.

Table 1. Accounting software, more than 5,000 installations [15, own elaboration]

\begin{tabular}{|c|c|c|c|c|c|c|}
\hline $\begin{array}{l}\text { Name of prod- } \\
\text { uct }\end{array}$ & Name o & f producer & $\begin{array}{l}\text { Number } \\
\text { of instal- } \\
\text { lations }\end{array}$ & $\begin{array}{l}\text { Size of the } \\
\text { biggest in- } \\
\text { stallation }\end{array}$ & $\begin{array}{l}\text { Workers } \\
\text { on hot- } \\
\text { line }\end{array}$ & $\begin{array}{l}\text { Number of } \\
\text { consultants of } \\
\text { the product }\end{array}$ \\
\hline Pohoda & Stormw & vare & $200000+$ & 60 & 76 & 100 \\
\hline Money S3 & Solitea & CR & 60000 & 50 & 65 & 120 \\
\hline Ekonom & Elisoft & & 35000 & 25 & 8 & 15 \\
\hline Účto Tichý & Tichý \& & spol. & 24200 & & 4 & A few tens \\
\hline Abra Gen & Abra & Software & 9400 & & 20 & 64 \\
\hline Helios Orange & Asseco & Solutions & 6088 & 250 & 101 & 203 \\
\hline $\begin{array}{l}\text { Stereo Ježek } \\
\text { SW }\end{array}$ & Ježek & Software & 5000 & & 8 & 44 \\
\hline
\end{tabular}

Company Solitea Česká republika (Solitea CR) was till October 2017 known and named as Cígler Software. The biggest installation recorded product Helios Orange with 250 installations. Pohoda with 60 and Money S3 with 50 were on the next positions. Účto Tichý and Stereo Ježek Software is focused mostly on the small companies. From accessible sources it is possible to mention, that the biggest number of workers on hot-line is in company Asseco Solutions. It can be connected also with their other products that they offer to bigger companies. The smallest number of workers on hotline recorded Účto Tichý with 4 employees and Ekonom and Stereo Ježek Software with 8 workers. Asseco has also the biggest number of consultants. Less consultants recorded Ekonom. Účto Tichý and Stereo Ježek Software. Účto Tichý and Ježek Software closely cooperate. Účto Tichý has software for individuals (sole traders) that lead single-entry bookkeeping and Ježek Software for corporate bodies that lead double- 
entry bookkeeping. Pohoda, Money, Ekonom and also Abra offers both types of accounting used in the Czech Republic. Almost all companies actualize information about them. The newest one was done $11^{\text {th }}$ of June 2018 by Abra Software and Ekonom $6^{\text {th }}$ of June 2018. In $201815^{\text {th }}$ of March actualize also Solitea CR. Tichý \& spol. recorded the oldest data from $8^{\text {th }}$ of November 2016. Stormware with the biggest number of licences updated more than year ago $16^{\text {th }}$ of February and Ježek Software also $1^{\text {st }}$ of June.

\subsection{Accounting software, web pages and social networks}

In the next part of the research there were analysed social networks Facebook, Twitter, Instagram, YouTube, Google+ and LinkedIn in the connection with producers of accounting software in the Czech Republic. It was searched whether or not have the producers of accounting software account on the widely used social network Facebook or on others. Accounts of the individual brands were searched on the all mentioned social networks. Results are presented in table 2.

Table 2. Use of social networks and direct links between companies www and social networks [16-19, own elaboration]

\begin{tabular}{lccccccccccc}
\hline & \multicolumn{2}{l}{ Facebook } & \multicolumn{2}{c}{ YouTube } & \multicolumn{2}{c}{ Twitter } & \multicolumn{2}{c}{ Google+ } & \multicolumn{2}{c}{ Linkedin } \\
\hline & Use & Link & Use & Link & Use & Link & Use & Link & Use & Link \\
Pohoda & $\mathrm{X}$ & $\mathrm{X}$ & $\mathrm{X}$ & $\mathrm{X}$ & $\mathrm{X}$ & $\mathrm{X}$ & $\mathrm{X}$ & $\mathrm{X}$ & $\mathrm{X}$ & - \\
Money S3 & $\mathrm{X}$ & $\mathrm{X}$ & $\mathrm{X}$ & - & $\mathrm{X}$ & - & $\mathrm{X}$ & $\mathrm{X}$ & $\mathrm{X}$ & $\mathrm{X}$ \\
Ekonom & $\mathrm{X}$ & $\mathrm{X}$ & $\mathrm{X}$ & - & $\mathrm{X}$ & - & $\mathrm{X}$ & - & $\mathrm{X}$ & $\mathrm{X}$ \\
Účto Tichý & $\mathrm{X}$ & - & $\mathrm{X}$ & - & - & - & - & - & - & - \\
Abra Gen & $\mathrm{X}$ & $\mathrm{X}$ & $\mathrm{X}$ & $\mathrm{X}$ & $\mathrm{X}$ & $\mathrm{X}$ & $\mathrm{X}$ & $\mathrm{X}$ & $\mathrm{X}$ & $\mathrm{X}$ \\
Helios Orange & $\mathrm{X}$ & $\mathrm{X}$ & $\mathrm{X}$ & $\mathrm{X}$ & $\mathrm{X}$ & $\mathrm{X}$ & $\mathrm{X}$ & - & $\mathrm{X}$ & $\mathrm{X}$ \\
Stereo Ježek SW & $\mathrm{X}$ & $\mathrm{X}$ & $\mathrm{X}$ & - & $\mathrm{X}$ & $\mathrm{X}$ & $\mathrm{X}$ & $\mathrm{X}$ & $\mathrm{X}$ & - \\
\hline
\end{tabular}

It was founded that all producers use social networks Facebook and YouTube for communication with audience. Twitter and Google+ use all producers instead Tichý \& spol. Table also presents interconnection between web pages and direct links on social networks where their accounts were founded. It was founded that all companies instead Účto Tichý have direct links of their Facebook profile. Even though all companies use YouTube, the direct link from the first page uses only two companies Abra Software and Asseco Solutions. Next link has also Stormware but it is necessary to click more times. Twitter has not links on the websites in all companies. Elisoft and Solitea CR is missing those information. Links on Google+ were not found for companies Asseco Solutions and Elisoft. Links on Linkeid in missing in company Stormware and Ježek Software. Company Abra is the only one that have links on all social networks that they use. Other social networks are also used. Solitea CR has the link on their Skype. Asseco Solutions use also blog and Elisoft use Instagram.

All producers instead Tichý \& spol. have produced and presented video courses for all free of charge. Abra Software have free training only for license owners. [20-26] 


\subsection{Producers of accounting software + Facebook + Socialbakers}

Producers of accounting software were put into analytics tools that offer Socialbakers. [14] The number of fans in the last year and their changes were indicated. The evaluation started on June 19, 2017 and ended on June 18, 2018. It was founded that the biggest group of fans on the social network Facebook has company Asseco Solutions. Number of their fans at the end of the monitored period was 11556.9518 fans were local (Czech Republic) - 81.12\%, 1560 from Slovakia (13.3\%) and 0.85\% from United Kingdom, $0.73 \%$ from Germany and $0.42 \%$ from USA. Solitea CR has 2868 fans at the end of the monitored period. Almost $93 \%$ were from the Czech Republic. Next countries were again Slovakia (5.04\%), Belgium, Germany and United Kingdom.

Number of fans of next companies, $\%$ and distribution of fans:

- Abra SW - 719, 90.72\%, Slovakia (4.99\%), Germany, United Kingdom, Indonesia

- Ježek SW - 380, 94.7\%, Germany, Slovakia, Canada, Nigeria

- Ekonom - 73, 92.86\%, United States, Serbia, Slovakia, Malaysia

- Stormware - 187, 84.12\%, Slovakia (13.53\%), Poland, Canada and Italy

- Účto Tichý - 42, $97.3 \%$ and Austria with 1 fan is $2.7 \%$.

Numbers of fans were changing in the monitored period. The difference between starting date for monitoring and ending day (19th of June $2017-18^{\text {th }}$ of June 2018) is presented in fig. 1.

Fig. 1. Increases and decreases of number of fans on Facebook in the last year [14, own elaboration]

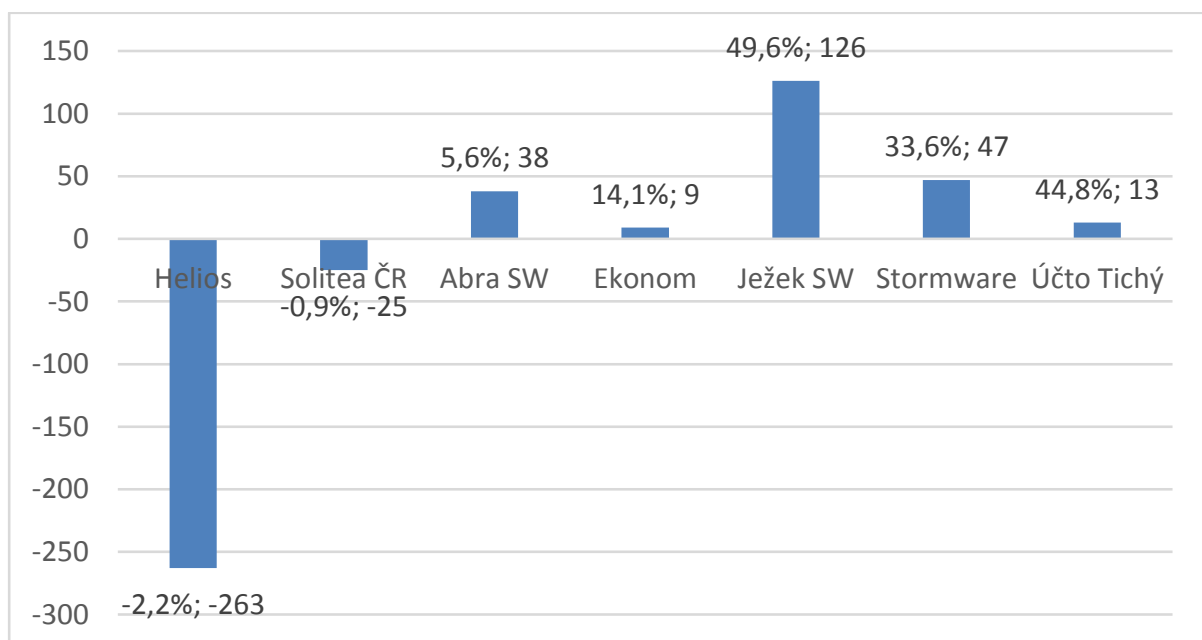

The largest increase was recorded in Ježek SW by 126 fans. It was also the highest \% growth. All companies monitored growth instead Helios and Solitea, but from the whole numbers they loss only $2.2 \%$ and $0.9 \%$ of fans in comparison with starting and ending period. 


\subsection{Optimal use of platforms by companies producing accounting software}

Recommended optimal Social Media Network portfolio for accounting firms in the Czech Republic is use of selected social networks. They were selected due functions that they provide and also they are widely used by citizens and companies.

- Facebook - use for posting content, provide organizational news, offer deals, introduce products and manage customer service relationships. It can be used periodically but mostly when something is new in the area.

- YouTube - using video to show how to use accounting software. It is recommended to use when some changes in the software is done to show how to use it in the new way. There can be uploaded also videos that are connected with FAQ.

- Twitter - through short news reports about news and actualization of products.

- Google+ - it is the social network that offers the most tools and features. It is recommended to use user profile as a publicly visible account of a user that is connected to many Google properties. Circles enables users to organize people into groups or lists for sharing across various Google products and services. Companies can use also Stream, Identity service, +1 Button, Google+ pages, Communities, Events, Discover, Photography etc.

- LinkedIn - use to inform for seeking of new employee. Current employees can inform about situation in the company from employee point of view.

- Instagram - use for posting of actual photo or video from the business environment.

Companies may use also WhatsApp, Viber, Blogs and other social networks if necessary. Important is to connect social networks with the www pages of companies. The links should be placed clearly on the first page and then if necessary by the individual topics.

\section{$5 \quad$ Conclusion and discussion}

Social networks fit knowledge management as they open the door to new ways of communication, enable development, editing, sharing and storing materials on the virtual platform. Social networks are nowadays one of the most popular and most often used channels to inform and communicate not only in the private sphere but also at business environment.

The goal of the article was to present the most often used accounting software, their producers in the connection with use of social networks by producers of accounting software and links with producer's web pages in the Czech Republic. The sub-goal was to present records gained from Socialbakers focused on the evolution of fans on Facebook and to state use of platforms by companies producing accounting software.

It has been founded that all producers use Facebook and YouTube. Twitter, Google+ and Linkedin use all companies instead Účto Tichý. Unfortunately not all used social networks and individual accounts have links on the websites of the companies. Elisoft has no 3 links, on YouTube, Twitter and Google+. Solitea CR missed two links, YouTube and Twitter. Stereo Ježek has not link on YouTube and Linkedin. Stormware 
has not presented link on Linkedin and Asseco Solution on Google+. Účto Tichý is the weakest in using social networks.

The largest share of the fans on Facebook has Asseco Solution followed by Solitea. After a big gap are Abra Software, Ježek Software, Ekonom and Stormware. Účto Tichý is in the last position with 42 fans. Most of the fans are from the Czech Republic. The second group were Slovakia. Reason can be also similar products that are sold in both countries. Asseco Solutions have the biggest share of users from abroad. Results show interesting fact. Pohoda, that is the most often used, has the third smallest record of fans, only 187. The largest increase of fans in the last year recorded Ježek Software and Stormware. On the contrary, the decrease recorded Asseco Solutions that has also the largest number of the fans and Solitea. In \% decrease is only $2.2 \%$ and $0.9 \%$ according to first and last date of the monitored period.

Companies can be advised to manage all of the listed social networks (Facebook, YouTube, Twitter, Google+, LinkedIn and Instagram) and to get benefits from their use in order to retain existing customers and at the same time gain new customers. Even though social networking means additional costs for companies, they can inform professional audience and customers about new developments in the area of accounting and accounting products just now. It is less expensive than printed form or other types of marketing tools.

In future there is potential for an interesting research and area of exploration. It can be also investigated topics of posts, number of posts, like, focusing, tracking, tweets, use of mobile apps, their use, training and posts and use of YouTube.

\section{Acknowledgement}

This paper is supported by specific project No. 2103/2018 "Investment evaluation within concept Industry 4.0" at Faculty of Informatics and Management, University of Hradec Kralove, Czech Republic. We would like to thank student Jan Hruška for cooperation in the processing of the article.

\section{References}

1. Svobodová, L, Černá, M.: Accounting, Economic and ERP Systems on the Czech Scene. Advanced Science Letters, 22(5-6), pp. 1170-1174 (2016).

2. O'Reilly, T.: What is Web 2.0: Design Patterns and Business Models for the next generation of software, http://www.oreillynet.com/pub/a/oreilly/tim/news/2005/09/30/what-is-web20.html, last accessed 2018/06/18

3. Barnes, J. Class and Committees in a Norwegian Island Parish. Human Relations, (7) pp. 39-58. (1954)

4. Černá, M., Svobodová, L, Haviger, J.: Perception and Utilization of Facebook by University Students: Case Study. Proceedings of the 15th European Conference on e-learning (ECEL), pp. 105-113 (2016).

5. Svobodová, L.: Utilization and Benefits of YouTube for the Educational Purposes: a Review Study. Proceedings of the 15th European Conference on e-learning, pp. $789-793$ (2016). 
6. Eurostat. Digital economy and society statistics - households and individuals http://ec.europa.eu/eurostat/statistics-explained/index.php?title=Digital_economy_and_society_statistics_-_households_and_individuals (2017), last accessed 2018/06/18

7. Czech statistical office. https://www.czso.cz/csu/czso/information-society-in-figures, last accessed 2018/06/18

8. Social media - Definition and More from the Free Merriam. Webster Dictionary. http://www.merriam-webster.com/dictionary/social\%20media, last accessed 2018/06/18

9. Janouch, V.: Internetový marketing Prosad’te se na webu a sociálních sítích. Brno: Computer Press, 216 p. (2010)

10. Colicev, A, O'Connor, P. Vinzi, VE.: Is Investing in Social Media Really Worth It? How Brand Actions and User Actions Influence Brand Value. Service Science. Vol. 8(2), pp. 152168 (2016).

11. Agostino, D. and Sidorova, Y. A performance measurement system to quantify the contribution of social media: new requirements for metrics and methods, Measuring Business Excellence, Vol. 20(2), pp. 38-51 (2016).

12. Du, H., and W. Jiang. Do social media matter? Initial empirical evidence. Journal of Information Systems. Vol. 29(2) (2015).

13. Dočkalová, P.: Criteria for selection of an economic system. IT Systems: With an overview of the world of information technology, 11/2008, http://www.systemonline.cz/ekonomickesystemy/kriteria-pick-economic-system-1.htm, last accessed 2018/06/18

14. Socialbakers, https://suite.socialbakers.com/234916/analytics/?c-d1=last-30\&c-l=0, last accessed 2018/06/18

15. System online, http://www.systemonline.cz/prehled-informacnich-systemu/ekonomickesystemy, last accessed 2018/06/18

16. Facebook, https://www.facebook.com/, last accessed 2018/06/18

17. Instagram, https://www.instagram.com/, last accessed 2018/06/18

18. Twitter, https://twitter.com/, last accessed 2018/06/18

19. YouTube, https://www.youtube.com/, last accessed 2018/06/18

20. Abra Software, https://www.abra.eu/, last accessed 2018/06/18

21. Asseco Solutions, http://www.helios.eu/, last accessed 2018/06/18

22. Elisoft, Ekonom, http://www.ekonom-system.cz/cz/home, last accessed 2018/06/18

23. Ježek Software, https://www.jezeksw.cz/, last accessed 2018/06/18

24. Solitea Česká republika, http://www.money.cz/, last accessed 2018/06/18

25. Stormware, https://www.stormware.cz/, last accessed 2018/06/18

26. Účto Tichý, https://www.ucto-tichy.cz/, last accessed 2018/06/18

27. The Purpose of Facebook, https://www.techwalla.com/articles/the-purpose-of-facebook, last accessed 2018/07/22

28. What is the purpose of YouTube?, https://www.quora.com/What-is-the-purpose-ofYouTube, last accessed 2018/07/22

29. What is the main purpose of Twitter?, https://www.quora.com/What-is-the-main-purposeof-Twitter, last accessed 2018/07/22

30. What is the main purpose for Google+?, https://www.quora.com/What-is-the-main-purposefor-Google+, last accessed 2018/07/22

31. Glusman, A. 7 Reasons Why You Should Be Using Google+ For Your Business, https://www.business2community.com/google-plus/7-reasons-using-google-business01126869, last accessed 2018/07/22

32. Cornell, S. Purpose Of LinkedIn, https://smallbusiness.chron.com/purpose-linkedin62179.html, last accessed 2018/07/22

33. Instagram, https://en.wikipedia.org/wiki/Instagram, last accessed 2018/07/22 